\title{
Research and Practice on the Design and Implementation of the Teaching Development Project of Undergraduate Colleges and Universities
}

\author{
Taking Jilin Agricultural University as an example
}

\author{
Zhao Xianglian \\ Center for Teaching and Learning Development \\ Jilin Agricultural University \\ Changchun, China
}

\author{
Wang Shuli \\ Center for Teaching and Learning Development \\ Jilin Agricultural University \\ Changchun, China
}

\author{
Zhou Jianzhong \\ Center for Teaching and Learning Development \\ Jilin Agricultural University \\ Changchun, China \\ 15387186@qq.com
}

\begin{abstract}
Teachers are the most valuable resources in the undergraduate colleges and universities. The development of the teachers is an important factor to improve the competitiveness of colleges and make continuous progress. In this thesis, based on the demand of the teachers' development, we put forward the general design that fits the development project of the teachers and carry on the project. The author used the practical work as material and investigation as the main method. The author explores the implementation mode which promotes the development project of the teachers of undergraduate universities, improving the general level of the teachers by focusing on the youth and backbone teacher training, promoting the teachers' idea collision by regarding communication in teaching as an opportunity, keep improving the teaching quality by means of quality evaluation. It makes it clearer that only when the teaching development project of teachers is implemented, can the teaching ability of the college teachers be improved.
\end{abstract}

Keywords-Local agricultural colleges; teacher development needs; teacher development project

\section{INTRODUCTION}

Improving the teaching ability of teachers in Colleges and universities is the basis of improving the quality of higher education, and it is necessary to improve the quality of higher education. In June 2014, the Education Department of Jilin province should be required to set up a teacher education development center (hereinafter referred to as the center), formerly known as the Faculty of Personnel Department of Jilin Agricultural University and the quality management department of Jilin Agricultural University. Since the

Project: In 2014,research on the teaching of higher education in Jilin Province, the research project of higher education in local colleges and universities. 2012 human and social sciences of the Ministry of Education Planning fund project, the three provinces of Northeast China's innovation ability of young teachers in the status quo and Countermeasures to enhance the study, the host: Zhou Jian Zhong. Contract number: 12YJAZH211 establishment of the strict following the "stimulate the potential of teachers, the pursuit of excellence in teaching, integration of quality resources, to promote the development of teachers, to carry out exchange evaluation, improve teaching quality," the mission and purpose, and strive to carry out the work, forming a clear framework for the basic work. And Jilin province science and Technology Association, Jilin Province, college teachers training and innovation service platform and the Jilin provincial teacher education development demonstration center.

\section{The FOLLOWING PRINCIPLES ARE STRICTY FOLLOWED IN THE EARLY PERIOD OF THE CENTER.}

\section{A. Establish the Academic Idea, the Goal is clear.}

Conception is the guide of action which the center of the teaching as an academic, setting up a "teaching academic" as the center of the idea, adhere to the teaching of academic[1]. University Teaching Development Center has been actively promoting the concept of teaching, creating an atmosphere of academic atmosphere, helping teachers to develop academic consciousness, encourage teachers to pursue teaching, form a good teaching academic culture, so that teachers can carry out teaching research, so as to improve the level of teachers.

\section{B. Personnel Configuration is Complete, Reasonable Division of Labor}

Man is the most important resource, any one of the work needs to be executed, and the personnel allocation is the cornerstone of the University Teachers' education development center. The center of the construction of complex, system, to carry out such work should not only have strong organizational ability of the leadership, responsible for the smooth operation of the center, but also have a good command of the 
professional knowledge of the staff, service center teachers' teaching.

\section{Comprehensive Service Projects, Highlighting Features}

To meet the needs of the development of teachers' teaching, to provide a flexible and diverse service project. These programs cover all the schools in the school, and provide the services that cover all the professional stages of the teacher. At the same time, the center of the project not only the research activities of the teachers, but also the individual of the guidance; there are general service projects, but also the characteristics of activities such as lunch, workshop, in order to attract more and more teachers to participate in the construction of the center. Different levels of teacher education needs to implement different development projects. In order to meet the needs of the school and teachers, the center of each semester also continue to provide new services, such as a visit to the Ministry of scientific research platform and other projects[2].

\section{To TAKE Shape OF THE WORK PATTERn CENTER}

\section{A. Focus on Youth and Backbone Teachers' Training, and Promote the Overall Level of Teachers}

In order to include the new teachers and the teachers as the main training object, the combination of long-term and shortterm training has been formed, and the combination of theoretical study and practice, the combination of theoretical study and practical training, and the combination of tutor guidance and autonomous learning are four. Within one year of training 488 teachers. The new teacher training program for 77 people (2). Micro lesson design and production of 50 training, 159 domestic short-term training, national quality courses network training 104 people, summer social practice 56 people, visiting scholars 12 people, visiting and cooperative research 9 people; 21 foreign training. At the same time, 9 people receive different levels of learning[3].

\section{B. To Promote the Concept of Teachers in the Collision With the Opportunity of Teaching}

According to the teachers' teaching and students' learning, and teachers professional development and career planning to carry out famous pulpit, tea, workshops, open classroom series of activities around the hotspot.

To set up the communication platform, to promote the exchange and experience sharing between students and teachers, to strengthen the promotion and application of advanced educational ideas, teaching methods and teachers' skills to meet the needs of teachers' growth and development.

\section{1) tea will speak one's mind freely relaxed.}

Held the young teachers study abroad experience exchange ", the change of teaching ideas and the university classroom teaching optimization 8 tea will, for teachers to provide a can freely exchange our experiences in teaching, discuss the teaching problems and countermeasures, places and platform to share insights on life. Most of the teachers like this relaxed atmosphere, because a lot of harvest.

\section{2) Foreign experts frequently visit, famous pulpit benefit}

Teacher education development center has 2 invited USA BARSTOW college professor, Professor of Chinese Association Secretary America long, President, chairman of the board of supervisors professor Jiang Zhenying came to our school, the "USA higher education", "how do university teachers" academic exchanges; invited the United States University of California riverside ecology Professor, director of the international ecological and Sustainable Development Research Center, CO director of international ecological research in arid region, China (government) and co-director of the joint research center of agricultural ecology and sustainable development, "Ecological Complexity" (Elsevier) magazine editor, academician Li Bailian, the "Anthropocene era of social, economic and ecological harmony of the relevant theories and methods to explore," "ecological life, innovation and Research on SCI writing" as the theme of the multi period name / academic exchange activities; invited the Canadian province of Quebec College (Vanier College) and officer John Albert (John Abbott College) Zhu Xiaoyang entitled "the teacher teaching idea and ability centered -- experience and exploration from Quebec"

\section{3) The classroom is open, the teaching activity is rich and colorful}

Three semesters have opened 48 teachers in the classroom, instructor recommended by the Institute, center designated Teacher Education at all levels, all kinds of teaching competition award-winning teachers, courses and excellent courses, responsible person, excellent young teachers. 48 teachers are open to the whole school teachers in the classroom, for teachers to observe and study.

\section{4) The purpose is clear, the teaching workshop lead in place}

Held four "student learning teaching thinking and teaching design" workshops and invited the Northeast Normal University, Faculty of education, Wang Shufu lecture by professor. From Northeast Normal University humanities colleges, Jilin University of Finance and economics, Changchun Institute of Finance and economics and the teaching unit of our school teachers were attracted to participate in this workshop. The speaker is clear, for participating teachers lead in place. Give the participants a certain inspiration on how to design and to be familiar with the thinking of students, so as to carry out teaching activities better.

5) Improve the teaching ability, the activity of Microteaching wildly beating gongs and drums

2015 new 24 teachers into agricultural medicine group, medicine and agriculture group and industry and trade group, cultural group four groups to the development of Microteaching in comprehensive on the eighth floor micro classroom. The micro teaching is divided into three stages. By the end of June, it has been successfully carried out the teachers on their own practice and expert comment on stage multi field. For the early 7 , the teaching assessment done enough preparation and the new teacher's teaching ability has been greatly improved[4]. 


\section{Promote the Continuous' Improvement of Teaching Quality by Means of Quality Evaluation.}

Based on the evaluation of undergraduate course, the teaching quality evaluation is the key to carry out regular lectures, inspection and special supervision work. Based on the basic data platform of Education Department, the basic state data collection, statistics, analysis and publication are carried out.98.27 average 159055290716 steering group and two cumulative 2014 Colonel steering lectures 200 passengers, school leaders to attend a lecture 45 people. It is the first time to organize level steering group leader is teaching, vice president of the University, teaching, teacher development center to carry out joint interim quality inspection, a sample of 530 people classroom, one by one to visit the colleges, relevant examination and feedback, sampling Jilin Architectural University classroom theory teaching order; to carry out online teaching evaluation work, participating teachers 745 people, curriculum, student participation people, teachers teaching evaluation; hold the student status management related knowledge to explain "seven games, the information transfer will be 1 , the information group members meeting 8 times. Collect the effective teaching information of more than 500, absorb 2014, 2015 new information member 200, to carry out the basic state data collection work of the Ministry of education.

\section{To Support Service for the Purpose, to Promote Teachers' Teaching Ability}

Around teacher teaching, scientific research and other major activities and problems encountered in the process of growth, there are targeted to carry out teaching consultation, educational technology support and all kinds of resource sharing services, establish a personalized support service system to meet the needs of different disciplines, different types, in different stages of development. Jilin Province college teachers training and innovation service platform, in the service of the school teachers, and strive to radiation Province University.

\section{CONCLUSION}

Faculty development is the effective strategy and importa nt experience to promote university foundation ability, promote the university sustainable development. Continuously improve teachers' teaching ability and teaching research ability by resea rch leading, team building, training communication, etc. Ensur e the stability of the teaching work, harmonious and sustainable development.

\section{REFERENCES}

[1] Crow M L, Milton O, Moomaw W E, et al. Faculty development centers in southern universities[M]. Atalanta, GA: Southern Region Education Board.1976:3

[2] Xiangjian Chen, Yuewen $\mathrm{Wu}$, The problems and suggestion in the development of teachers in universities, Education Exploration, 2014, 3:105-106.(In Chinese)

[3] Hongyan Wang, Xiangming Chen, "Orientation of new teachers: oneself, discipline and students", Contemporary Educational Science, 2008, 9: 27-29. (In Chinese)

[4] Jerry G. Gaff. Toward Faculty Renewal: Advances in Faculty, Instructional, and Organizational Development (San Francisco: JosseyBass.1975), 14-16. 